\title{
Change and continuity in the academic profession: Finnish universities as living labs
}

\author{
Taru Siekkinen $^{1}$ (D) Elias Pekkola ${ }^{2} \cdot$ Teresa Carvalho $^{3}$
}

Published online: 4 July 2019

(C) The Author(s) 2019

\begin{abstract}
The academic profession is challenged by the changing environment. Global trends, such as managerialism and new public management, have been influencing all public organizations, including universities. The academic profession is dynamic by its nature; it reflects any changes in its environment. However, the academic profession is also characterized by continuity. In this study, we describe the current changes and continuities of the academic profession in Finland, as perceived by top and middle managers employed in Finnish Universities. We found out that logics and values by organizational professionalism are emphasized; however, occupational professionalism is also deeply rooted in the practices of Finnish universities. Additionally, we found out that changes are often associated with managerial values, such as control and evaluation, and in contrast, the continuities of academic work are commonly related to professorial authority and academic identity. These two aspects of the profession and organization are not opposite, they occur simultaneously; however, there are tensions between them. In this article, we would like to emphasize that change of the academic profession is a hybrid, there exists both, changes and continuities in the logics and values related to the profession and the organization.
\end{abstract}

Keywords Academic profession · Managerialism · New public management $\cdot$ Change $\cdot$ Universities

Electronic supplementary material The online version of this article (https://doi.org/10.1007/s10734-01900422-3) contains supplementary material, which is available to authorized users.

Taru Siekkinen

taru.siekkinen@jyu.fi

1 Finnish Institute for Educational Research, University of Jyväskylä, PO Box 35, FI-40014 Jyväskylä, Finland

2 Faculty of Management and Business, Tampere University, FI-33014 Tampere University, Finland

3 Center for Research in Higher Education Policies (CIPES), University of Aveiro, Campus

Universitário de Santiago, 3810-193 Aveiro, Portugal 


\section{Introduction}

All professions are challenged by the changing environment (Carvalho 2014). The academic profession is of no exception; it is dynamic by nature and therefore reflects any changes in its environment (Musselin 2007). However, professional groups and professionalism are also characterized by continuity. To foster a deeper understanding of the academic profession and its dynamic nature, we need to explore how it is changing, adapting, and/or resisting (Evetts 2010; Pekkola 2009).

The work of academic professionals has become increasingly managed, evaluated, and measured using techniques derived from profit organizations, aiming to maximize their performance. Many authors worry about the deteriorating impact of these new structures and practices and the organizational values they impose, which can also threaten the identity of academics and decrease the quality of academic work (e.g., Kallio and Kallio 2014; MartinSardesai and Guthrie 2018; Ylijoki and Ursin 2015). However, changes are not always "bad", and continuities are not always "good"; for instance, a growing number of university employees are asking for transparency, clear reward structures, and equity while opposing managerial and bureaucratic practices, but hail collegial practices that can be exclusive and oligarchic by nature (cf. Pekkola 2014).

Academics working in universities are situated in an interface of professional and organizational values, practices, and logics. In this article, we study the perceptions of top and middle university managers on how organizational and occupational professionalism (Evetts 2009) coexist in Finnish universities. These aspects are approached by applying Evetts' (2009) framework of the changes and continuities in professional values. We emphasize that these logics are not entirely independent nor conflicting, but intertwined and parallel, thus creating a hybrid. However, to identify the different aspects of the hybridity, it is useful to examine the development of this dichotomy.

The article is organized as follows. First, we will describe the global trends that have an influence on the work and working environment of academics, such as new public management (NPM) and managerialism. Second, we will address the general features of the changing profession, introducing the ideal types of organizational and occupational professionalism (Evetts 2009) as well as the hybrid model (e.g., Noordegraaf 2015), and also the changes and continuities in professional values (Evetts 2009). Third, we will discuss the changing academic profession and fourth, the Finnish context. Fifth, we will describe the qualitative data used in this study, and sixth, we will analyse our data using Evetts' (2009) theoretical framework on changes and continuities in professionalism. At the end, we will discuss the results and identify the changes and continuities, as well as the hybrid nature of academic profession.

\section{Global policy trends influencing the academic profession}

Direct and indirect economic pressures on higher education compel universities to build more entrepreneurial and corporate structures into their activities (Carvalho and Santiago 2010). Additionally, universities have adapted more "market-like" behavior (Slaughter and Leslie 1997). Two overlapping global trends in public policy and administration have had a significant influence on the academic profession: NPM and managerialism. Although these trends are interconnected, NPM emphasizes more efficient public organizations whereas managerialism describes an ideology of management (Deem and Brehony 2005). 
NPM emerged from the UK in the 1980s, in response to the peoples' demands for a cheaper and more efficient public sector during times of economic recession (Evetts 2009; Ferlie et al. 2008). NPM has influenced the implementation of numerous reforms in European higher education, which aimed to increase productivity and efficiency. To accomplish these goals, institutes of higher education began implementing performance evaluations and monitoring their research and teaching activities. In addition, as institutional governance held a central position in this change, academic leaders were expected to take on a managerial role. The power of collegial bodies in universities therefore shrunk while the power of managers and other non-academic leaders expanded (Bleiklie et al. 2011; Deem 1998, 2004). Marginson (2008, p. 270) described NPM techniques in universities, which can include the following:

- Funding-based economic incentives,

- User-driven production,

- Product formats,

- The pricing and sale of outputs,

- Entrepreneurial production,

- Output monitoring and measurements,

- Competitive ranking of personnel and of institutions,

- Performance management,

- Performance pay,

- Contracts with and incentives to partner with industry and commercialize research motivations and products,

- Systems of accountability audit including contracts with government that implement external controls.

All listed techniques can be seen as more or less formal ways of controlling and counting academic work and outputs. This has a direct or indirect impact on the coordination and values of academic work.

Managerialism (or new managerialism [cf. Deem 2004; Deem and Brehony 2005]) is an ideology born from the earlier and narrower concept of "management". Under this ideology, managers believe that they have advanced knowledge and the know-how to run an organization efficiently. Recently, managerialism has spread from applications in business to those in public institutions, as well as to society at large (Deem and Brehony 2005; Klikauer 2015). Managerialism emphasizes competition, the marketization of public sector services, and monitoring efficiency through performance evaluations and outcome measurements (Deem 1998). Its influence is greatest when "professionality is replaced by accountability; collegiality by competition and interpersonal performative comparison" (Ball 1997, p. 261).

In today's universities, management is seen as a central tool for answering the needs of the changing external environment (Kogan and Teichler 2007; Shah 2013, p. 28; Shah and Sid Nair 2014). This tool has taken up a significant role in universities, thus increasing the power of managers and especially deans (Deem and Brehony 2005). University managers constitute a group of their own, and the division between them and academics who do not hold a managerial role is rather large (Deem 2004; Pekkola et al. 2018). However, there also exists an opposite trend in which the roles of academics are increasingly hybridized as the activities of higher education change (Kogan and Teichler 2007; Musselin 2007; Whitchurch 2008). 


\section{The changing concept of professionalism in academic work}

NPM and managerialism are important factors in the development of the academic profession. Evetts (2009) has been studying the influence of NPM on professional groups and professionalism. She argues that professionalism is changing and distinguished two (ideal, heuristic) types of professionalism (see Table 1):

1. Organizational professionalism is manifested by a discourse of control used by the organizations' managers. It involves rational-legal forms of authority, standardized work procedures and practices, and hierarchical structures of decision-making and authority, as well as accountability and performance review. These all are related to managerialism, which is supported and emphasized by these practices and principles.

2. Occupational professionalism is manifested by discourse constructed in professional groups, involving collegial authority. This authority is based on practitioner autonomy, assessment, and discretionary judgement. The relations between the practitioners and employers (as well as the clients) are based on trust. Control is operationalized by the practitioners themselves, which are guided by the codes of their professional ethics (Evetts 2009, p. 251).

These two concepts describe the ideal, heuristic types of organizational and occupational professionalism. While the newer concept of organizational professionalism is exposed to and integrated with the values and principles of NPM and managerialism, occupational professionalism is based on professional values and ethics (Evetts 2009). In practice, however, these concepts are blurred; they occur simultaneously and as a hybrid (Noordegraaf 2015). Tight (2014) has stated that in higher education, these two aspects are not dichotomous, and they both are important for the future of higher education.

Hybridism has been studied especially in the area of the public administration and organizational research (see e.g., Johanson and Vakkuri 2018). There are also recent attempts to understand the hybridity in the context of professional work (Noordegraaf 2015) and management positions in professional work (Mcgivern et al. 2015; Hendrikx and van Gestel 2017). In higher education research, it has recently gained an increasing amount of attention (Brückmann and Carvalho 2018; Lepori 2016). However, already Clark stated that in higher

Table 1 Two ideal types of professionalism in knowledge-based work (adapted from Evetts 2009)

\begin{tabular}{|c|c|}
\hline Organizational professionalism & Occupational professionalism \\
\hline $\begin{array}{l}\text { Discourse of control used increasingly by managers in work } \\
\text { organizations }\end{array}$ & $\begin{array}{l}\text { Discourse constructed within professional } \\
\text { groups }\end{array}$ \\
\hline Rational-legal forms of authority & Collegial authority \\
\hline Standardized procedures & $\begin{array}{l}\text { Discretion and occupational control of the } \\
\text { work }\end{array}$ \\
\hline Hierarchical structures of authority and decision-making & Practitioner trust by both clients and employers \\
\hline Managerialism & Controls operationalized by practitioners \\
\hline $\begin{array}{l}\text { Accountability and externalized forms of regulation, target } \\
\text { setting, and performance review }\end{array}$ & $\begin{array}{l}\text { Professional ethics monitored by institutions } \\
\text { and associations }\end{array}$ \\
\hline Linked to Weberian models of organization & $\begin{array}{l}\text { Located in Durkheim's model of occupations } \\
\text { as moral communities }\end{array}$ \\
\hline
\end{tabular}


education, hybrid principles exist (Clark 1983). Noordegraaf described how two aspects, managerial and professional, come together $(2015,6)$ :

"Professional work becomes a matter of combining professional and managerial principles, which do not so much create 'controlled professionalism' but more ambivalent, balanced, and subtle forms of 'managed professionalism' - professional action is positioned within managed and organized surroundings that both respect and restrain professional spaces."

In universities, hybridity has many implications. The roles of academics are increasingly mixed. Not only they become part of conducting the organizational control but also they become part of the control; the power of "manager-academics" in these new institutional frames has been increased (Deem 2004; see also Tight 2014). One example of implications of hybridism in universities can be found in the issues arising on the concrete level of activities; for example, the performance evaluations. In hybrid universities, the performance is redefined when it should meet not only the requirements of the scientific community but simultaneously other stakeholders as well, and questions such as "how is the performativity of universities produced?" arises (Johanson and Vakkuri 2018, 135-138).

However, in addition to aspects of change in the academic profession, there are continuities, which are those parts of professionalism that remain in the possession of the professional group itself and resist the change (Evetts 2009, 245). In Evetts' framework of changes and continuities in professionalism $(2009,257)$ (see Table 2 below), "Changes" include characteristics describing the nature of organizational professionalism influenced by NPM, such as control, evaluation, and competition. "Continuities", in turn, include characteristics which describe the nature of traditional occupational professionalism, such as identity, knowledge, and collegial relations.

Table 2 Changes and continuities in professionalism and in the academic profession (adapted and developed by the present authors based on Evetts 2009, p. 257). Analytical categories by current authors

\begin{tabular}{|c|c|c|c|}
\hline Changes & Continuities & $\begin{array}{l}\text { Analytical categories of } \\
\text { change in the academic } \\
\text { profession }\end{array}$ & $\begin{array}{l}\text { Analytical categories of } \\
\text { continuity in the } \\
\text { academic profession }\end{array}$ \\
\hline $\begin{array}{l}\text { Governance of multiple } \\
\text { stakeholders }\end{array}$ & Authority of professionals & \multirow{4}{*}{$\begin{array}{l}\text { Policies on academic } \\
\text { work and } \\
\text { management }\end{array}$} & \multirow{4}{*}{$\begin{array}{l}\text { Power and authority } \\
\text { of academic } \\
\text { professionals }\end{array}$} \\
\hline $\begin{array}{l}\text { Management based on } \\
\text { hierarchy }\end{array}$ & $\begin{array}{l}\text { Legitimacy based on esoteric } \\
\text { knowledge }\end{array}$ & & \\
\hline $\begin{array}{l}\text { Introduction of external } \\
\text { forms of regulation }\end{array}$ & $\begin{array}{l}\text { Maintaining prestige, status, } \\
\text { power, dominance }\end{array}$ & & \\
\hline $\begin{array}{l}\text { Possible range of } \\
\text { solutions/procedures de- } \\
\text { fined by the organization }\end{array}$ & $\begin{array}{c}\text { Procedures and solutions } \\
\text { discussed and agreed } \\
\text { within specialist teams }\end{array}$ & & \\
\hline Financial control & Respect, trust & \multirow[t]{4}{*}{ Control and evaluation } & \multirow{4}{*}{$\begin{array}{l}\text { Trust, competence, } \\
\text { identity, and work } \\
\text { culture }\end{array}$} \\
\hline Audit and measurement & Competence, knowledge & & \\
\hline $\begin{array}{l}\text { Targets and performance } \\
\text { indicators }\end{array}$ & Identity and work culture & & \\
\hline $\begin{array}{l}\text { Organizational control of } \\
\text { work priorities }\end{array}$ & $\begin{array}{l}\text { Gender differences in careers } \\
\text { and strategies }\end{array}$ & & \\
\hline Work standardization & $\begin{array}{l}\text { Discretion to deal with } \\
\text { complex cases }\end{array}$ & \multirow[t]{2}{*}{$\begin{array}{l}\text { Standardization and } \\
\text { competition }\end{array}$} & \multirow[t]{2}{*}{$\begin{array}{l}\text { Diversity and collegial } \\
\text { relations }\end{array}$} \\
\hline Competition, individualism & $\begin{array}{l}\text { Collegial relations and } \\
\text { jurisdictional strategies }\end{array}$ & & \\
\hline
\end{tabular}


Table 2 is developed by the authors by combining Evetts' categories (some of them are developed by authors as well) into three analytical categories, which more clearly describe the changes and continuities in the academic profession. As seen in Table 2, the three analytical categories of change in the academic profession are "policies on academic work and management", "control and evaluation", and "standardisation and competition". From the aspect of continuity, these three analytical categories are "power and authority of academic professionals", "trust, competence, identity, and working culture", and "diversity and collegial relations".

\section{The changing academic profession}

The academic profession differs from many other professions in that it carries and shapes the knowledge exploited by other professions (Höhle and Teichler 2013). This role of academics as knowledge producers who determine the knowledge needed to generate professional skills and practices has led to its classification as a "meta-profession" (Perking 1969; Carvalho 2017).

The academic profession is heterogeneous, including different kind of subgroups (Teichler 2010; Carvalho 2017), which can also be defined by the discipline (Becher 1989; Välimaa 1998), institutional type (emphasis on research and/or teaching), and career stage (juniors versus seniors). One key aspect that characterizes the work of academic professionals is the autonomy regarding their work. This autonomy, which is especially enjoyed by professors, makes the profession hard to steer from the outside (Carvalho \& Diogo 2018; Evetts 2009).

Academic identity is one unifying aspect of this group, which is structured in the social processes of strong and stable communities (Henkel 2005). Identity is not stable but constantly reshaping and a reflexive project (Giddens 1991). Academic identities are increasingly differentiated and being polarized in Finnish universities. Some academics feel that they have won and some that they have lost in a new, more competitive environment (Ylijoki and Ursin 2015). In the new institutional environment, academic work and roles are getting more blurred and diversified (Musselin 2007; Whitchurch 2008), and therefore, the identities and roles of academics are becoming more mixed as well.

Academics' performance is increasingly evaluated by the organization (Kallio et al. 2015). One central area in which evaluations are implemented is recruitment and advancement. Traditionally, academic careers have been integrated into a hierarchical structure which maintains social closure (Weber 1978) while allowing for the recruitment of junior academics, thus ensuring the quality of their professional work (Goode 1957). However, currently, the academics and therefore recruitments are more bound to universities, when the staff are seen more as their strategic assets; human resources and recruitment are targeted more in to universities' strategic areas (Rasmussen 2015; Siekkinen et al. 2016a).

\section{The Finnish context}

Finnish universities follow the global trends when higher education has become more marketoriented in recent years. In Finland, a new salary system based on performance was introduced in 2005, and the funding formula for universities has changed many times since the late 1990s, placing greater emphasis on efficiency and amount of degrees and journal publications. Since the mid-2000s, the Finnish government has implemented many reforms, labelled as "the 
Structural Development of the Finnish Higher Education System" with an aim to make the Finnish Higher Education system more reactive to global changes. Part of these reforms, in 2010, the new Universities Act came into effect, which made universities operate as employers. This meant that university employees began working with a working contract, instead of working in a public office, and universities began functioning as economic entities. These reforms made significant strides towards the adoption of a managerialistic culture in Finnish universities. After the reforms were implemented, Finnish universities began to enact their own human resource management (HRM) policies in a stronger and more visible manner (Kallio et al. 2015; Siekkinen et al. 2016a; Välimaa 2012; Ylijoki and Ursin 2015; Välimaa et al. 2014).

In addition, as part of those reforms, many university mergers have been conducted in recent decades in Finland. The biggest and the most famous one was the merger of the Aalto University in 2010, and 3 years after that, the merger of the Tampere University. These mergers have changed the field of higher education in Finland, as well as had an influence on the identities on many levels: organizational, disciplinary, and individual (Ylijoki and Ursin 2015; Vellamo et al. forthcoming; Välimaa et al. 2014).

The organizational structures in Finnish universities have been developed to be more standardized, e.g., in doctoral education (Kivistö et al. 2017) and academic careers, as well as recruitments (Pietilä 2015; Välimaa et al. 2016). The four-stage career model that is rather well implemented across universities follows the recommendations of the European model (e.g., The Ministry of Education and Culture [MEC] 2008; European Science Foundation 2009). In the four-stage career model, in the first career stage there are $\mathrm{PhD}$ students, in the second stage postdoctoral researchers, in the third stage the university teachers and lecturers, and finally in the fourth stage the professors and research directors. In concrete, this career structure is more a description of different career stages rather than a promise for a career progression in the individual level. Tenure tracks comprise of, depending on the university, three to five stages through which an individual proceeds via evaluation (stages are commonly: assistant/associate/full professor) (Pietilä 2015; Siekkinen et al. 2016a). Both of these career models have faced criticism, according to which the evaluations concentrate too much on research outputs and understate the teaching experience (Välimaa et al. 2016, see also Naidoo 2016 the negative influences on the competition).

Before the new career structures were introduced in Finnish universities, academic careers were more obscure, including many different job titles, and often only presented random opportunities for a career progression. Regardless of the formal introduction of departmental model in Finnish higher education, which took place already in 1960 s, the chair system has been influential until today. The recruitments have been based on open vacancies and the strong influence of professional evaluation and professors (Kivistö et al. 2019).

In Finnish academia, the level of internationalization has been rather low compared with many other countries. International students are regarded in national policies as potentially highly skilled labor and as a means to be globally competitive. However, international students often face challenges in a Finnish society, where the Finnish language skills are important (Välimaa and Weimer 2014). The same kind of challenges are experienced by the international staff in Finnish universities. To compare, in $2015,27 \%$ of all doctoral students in Finland were international, whereas with the professors the percentage was only 8 (Vipunen 2018). 


\section{Data and analysis}

This article includes an empirical analysis of semi-structured interviews, which were conducted in a research project, titled "The evaluation of the four-stage career model in Finnish universities" (Välimaa et al. 2016). During the project, academics and managers working in four Finnish, middle-sized, and multidisciplinary universities were interviewed in groups whose members were selected by their expertise regarding the new academic career structures. In each university, there were four interviews conducted. In this article, we will examine the responses of top and middle management, including rectors, vice rectors and provosts $(n=3)$; deans $(n=7)$; chief administrators $(n=2)$; personnel managers $(n=5)$; and heads of administration (i.e., faculty managers) $(n=5)$. The interviews included questions regarding the implementation and objectives of the four-stage career model and the tenure-track models in Finnish universities (Välimaa et al. 2016).

The interviews were conducted in Finnish and they were transcribed afterwards. The data analysis was performed by using two methods: thinking the interview data with a theory (Jackson and Mazzei 2013) and direct content analysis (Hsieh and Shannon 2005). In both, the researcher is familiar with a prior research and theory regarding the subject and the data is analysed by discussing with them. The data analysis started with reading carefully all the interviews, then selecting passages in which the interviewees described academic work or careers in universities, especially regarding change and continuity; professional and organizational activities. Subsequently, these passages were categorized with a help of code words and compared with analytical categories (see Table 2). The condensed results of this analysis are provided in Table 3 (see the Supplementary Material).

From Evetts' typology, we formed six analytical categories to describe the changes and continuities in the academic profession of Finland, as shown below:

a) Changes: policies on academic work and management; control and evaluation; standardization and competition.

b) Continuities: power and authority of academic professionals; trust, competence, identity, and work culture; diversity and collegial relations.

Next, we will describe how both the changes and continuities of the academic profession, as well as its analytical categories, manifested in the interviews.

\section{Changes}

\section{Policies on academic work and management}

In Finnish universities, middle management and especially deans are perceived to have more power, as they make many of the decisions related to recruitments and finance. According to top management representative:

In the old system, the faculty council dealt with management, whereas now such tasks related to faculty work are under the control of the dean. If the dean is active and aware of the situation, the dean can do a lot. (Academic top management)

According to interviews, depending on the competences of the dean, the new managerial ethos offers much more power in controlling faculty affairs, especially concerning finance. In 
addition, academic leadership is now seen as a comparable career choice to a purely academic career or working in administration, as one dean said:

...And I think that, little by little, in Finland we are also going in the direction of considering the duties of the rector, dean and maybe even faculty heads as careers of their own. (Dean)

In some universities, deans can also be professional managers coming from the private sector, rather than academics who have their professional roots in the university and are familiar with academic values and practices. These changes can influence the management culture in universities.

According to interviews, due to the increased emphasis of efficiency in academic work, structured practices, and new career models in universities, there needs to be a greater emphasis on HRM, as suggested by one middle manager:

The implementation of a four-stage career model requires strict management, maybe first in the faculties but also in each unit. (middle management - administrator)

University managers are responsible for the processes inside universities, such as HRM and finance, as well as some external processes, such as branding. These tasks have been emphasized since universities face requirements to be more efficient and competitive.

However, some strategic decisions made by top managers are not fully compatible with the operations of faculties in which teaching and research take place, as noted by one dean:

So [strategic decisions] should be conducted according to the Universities Act, which says that the university has three missions: research, teaching and societal impact; these missions should be in [the tenure-track] criteria. Nothing else can be considered sustainable, but now we have to take them "from the kitchen door". The reason why I have been emphasising research is related to the most important strategic goal of the university and the number-one priority of the rector: to strengthen our [status] as a research university. (Dean)

Funding drives universities to emphasize research (funding formula for Finnish universities: MEC 2018). As a consequence, the priorities of top management can be seen as problematic at the faculty level, regarding the ability to secure sufficient resources for teaching, as one interviewee stated.

\section{Control and evaluation}

Universities emphasize strong HRM while striving for greater output, as can be seen in their adoption of new career models, which reward good performance, especially in research. This phenomenon was also evident in the interviews:

We see [the early phase of a tenure-track career] as a qualification. We have a strong commitment to [the person whom]... we have chosen [for this] career path. And [this person's] qualification is up to her/his own personal performance. (Academic top management)

From the beginning of next year, we will shift this kind of personal salary negotiation [system] where... deans and a rector go through all the professors and... agree [to the terms] "face to face". (Dean) 
In today's universities, the discussion of career promotion is related more to employee performance in terms of meeting organizational needs rather than a part of an academic's professional process of occupational development. The culture of meritocracy is increasing the competition between academics; the career progression is dependent increasingly on the performance of an individual. Personal salary negotiations can provide more flexibility in remuneration; however, policies regarding the equal treatment of academics are challenged in such negotiations (e.g., the case in Finland in which male deans, by negotiating higher salaries for themselves, raised each other's salaries; Siekkinen et al. 2017).

\section{Standardization and competition}

In Finnish higher education, competition can be found from every level in universities; individual and organizational. Several interviewees recognized the downsides of competition in their universities:

So we have to compete in international labor markets, which is not easy... And we have to deal with these kinds of things so that we will be attractive in some way and be competitive in the long run. (Academic top management)

But what is perhaps more [worrying] in this current system is that [through] your own merits and that sort of [thing], you have to have competitive funding and have to have more proof; the previous path was more closed. So, this is more open and creates more anxiety because there is a pressure to [secure] that funding. (Middle management administrator)

Universities are competing to recruit the "best brains" in international labor markets, while academics are competing for posts and research funding. Under the "old system", resources were readily available to those employed by the university; now, academics must constantly and increasingly compete in an insecure environment; produce more outputs; and apply for funding if they wish to pursue an academic career. This creates stress and anxiety.

To measure outputs and plan operations more efficiently, universities must standardize their practices and structures related to academic work and careers. New career structures are a clear example of this process. In Finnish universities, the current career model has been divided into four stages and the tenure-track model has been divided into two to five stages, depending on the university, whereas before, those structures were more obscure and individuals' perceptions on how to progress in a career was unclear. The current recruitment system is also more standardized, now professionally implemented by each university's HRM. One interviewee described their university's career structure as follows:

Overall, there are five [career stages] at the moment, considering that we have "assistant one", "assistant two", "fixed-term associate"... so, six [positions] all together, because we have a "five-year associate", a "permanent associate" and a "full professor", and then we have this "distinguished professor". (Dean)

As one dean in a previous quote described, career stages can be rather standardized. It can lead to simplification; positions and titles are put into concrete, fixed categories to make them easier to assign and use, thus helping HRM manage academic staff in universities more efficiently. The following quote extrapolates further on this subject: 
We have quite inflexible [time] limits written [in the tenure-track model, such as under] three years and ten years, [but] most of the lecturers have already [been working for over] ten years. So, when our "TT" [tenure-track] positions are opened, [our most experienced lecturers] can't even apply to them; they can't proceed in [their careers]. (Dean)

According to a dean, standardization can also lead to inflexible practices, such as "academic age limits" (e.g., a lecturer is entitled to apply to a tenure-track position no later than 10 years from the date they obtained their doctoral degree). These practices can lead to an unequal treatment between academics, based on their work experience. Interviewees also mentioned the new mobility requirements for post-doctoral careers (i.e., a recent graduate must work in a different university, preferably outside Finland, after obtaining their doctoral degree), which are considered challenging for academics with families.

Several positive developments were mentioned as well; increasing standardized practices in universities has led to more predictable careers and salary progression for academics, like one dean said:

Yes, this has made evaluations clearer... [as well as] salary development. Before, it was way more unclear. Now we have clear criteria. (Dean)

Managers stated that current developments in evaluation criteria, salaries, and career progression are leading to more standardized structures, which allows academics to visualize their university careers in a more clear way.

Regarding Evetts' (2009) theoretical framework, the interviews gave the strong impression that Finnish universities are increasingly adopting organizational professionalism. A greater emphasis has been placed on management due to a complex, changing environment that values global and individual competitiveness. Additionally, academic staff and their work is increasingly controlled and evaluated, and internal practices and processes are now more standardized, having both positive and negative effects on academic work and career progression in universities.

\section{Continuities}

\section{Power and authority of academic professionals}

Despite the increasing managerial control in universities and the decreasing power of collegial bodies, the power has remained within the academic profession as well. This is especially the case for professors and deans, whose power and authority in university is rather stable. However, many of them are holding the management position as well. Additionally, especially professors enjoy academic autonomy, which is why they are sometimes hard to manage as a group. The interviewees described this phenomenon as follows:

When I was a dean [at my university], I did what I wanted and apologised afterwards. (Academic top management)

But then, when a professor holds that position and begins to do research, she/he has the constitutional right to freedom in his/her research, and that is challenging to manage. (Academic top management)

According to interviews, it may be that the academic content and traditions of universities are still tightly controlled by academic professionals, especially deans and professors, while their 
operational processes are more in the hands of administrators, to make organizational processes more efficient.

\section{Trust, competence, identity, and work culture}

Salaries in universities are commonly at the lower level than in other sectors, and grants especially. Academic work is still regarded partly as "vocation", meaning that in academic work, prestige is highly valued, sometimes over monetary rewards. One middle manager said in the interview:

...Everyone who comes to the university has to [accept a] decreased salary. But it is understandable, so [their] motives have to come from somewhere else, other than salary.

(Middle management - administrator)

The discourse of "vocation" can also be related to the means of neglecting higher salaries by managers in universities, and therefore exploitation of especially young researchers. However, academics' identities are not homogenous; some might find their working motivation from the monetary rewards.

Diverse identities can emerge also from the academics' attitude towards competition. Some might be satisfied with their current work tasks and position, which can be rather stable. In addition, academic work is diverse and some tasks need more continuity than others, like teaching and taking care of the teaching and research infrastructures.

When we think [about] the tasks of a university, part of those tasks are long term [and carry] a big responsibility, where stability and continuation are really important aspects.

(Academic top management)

In a current university environment, that is changing by nature, some rather stable aspects like "traditional" academic identity (related to roles in teaching and research), and a somewhat stable work culture can bring continuity and stability to a university environment. In addition, the constant presence of competition can generate anxiety for those academics who are rather satisfied with their work tasks and salaries already, and does not have great ambitions regarding their career progression.

However, some aspects of academic work and careers should change, so that they would be more modern despite the reliance on old traditions. Academic work culture has discriminated women, keeping them from having the same opportunities to proceed in their university careers as men. One dean reflects this issue in the interview:

Young women are not willing to come to this 'mill' that I just described [i.e. Finnish universities]. It's a hard choice because, at the same time, you should start a family and everything, and have children. (Dean)

For an early career researcher who wishes to have a family, and especially for women, the choice of whether to concentrate solely on a career or have children is difficult to make in a situation where the working culture does not support the work-life balance of mothers. Some managers might feel that it is purely a woman's individual choice, not a structural drawback, which creates indirect discrimination of women, and leads to excluding women from academic careers. However, this old-fashioned belief that women must choose between having a career or a family is slowly changing. 


\section{Diversity and collegial relations}

Sometimes, faculty decisions are not only based on strict rules and official policies; rather, they take the broader context into account as well as the needs of the faculty. The following quotes support this:

So, if I have 15 post-PhD, tenured positions [available], I will make a choice that I can't officially make: 10 [will be recruited from internal] staff and 5 from outsiders. (Dean)

I wish that we, in this case, will also move into more flexible thinking: that departments will [recruit new staff while keeping] in mind that, if there is some person who clearly shows [a] willing[ness] and [the] potential to, for example, [engage in] teaching development as a broad sense... So, for her/him, it is seen as valuable for developing the research. (Academic top management)

According to interviews, inside faculties, deans, and professors are sometimes supporting the career progression of their "own" staff, despite the official policy for open and international recruitment. Teaching also can be supported more in the faculty level instead of just supporting research. In addition, collegial relations are sometimes just as significant as the candidate's merits in recruitments, as indicated in the following quote:

Of course, it is written in the [career] model that... you can come from outside, but... because there are these people who have started here and gone forward in their career in this university... [if] someone tries to come there [from outside], [they] require good personal relationships with the supervisors and others [to] succeed. (Academic top management)

Progression in an academic career also might require strong networks, as one manager stated in the interview. Depending on the manager, this way of actions might have either negative or positive consequences for women's careers, as for other minorities as well. In addition, standardization in universities' processes may support more equal treatment of academics regarding salaries, access to research infrastructure, and occupational health care, as well as providing better opportunities to career progression. However, when standardized practices should guarantee the same treatment for all, these benefits may be only available for those who "fits in the box". Those, who are left outside, can be researchers who work with a grant funding without an employment contract to university, for example. In this case, professors and deans who have power within a faculty can support these academics and their career progression, if they will.

Comparing our analysis with Evetts's (2009) theoretical framework, it seems that occupational professionalism, in addition to organizational professionalism that was considered previously, is widely practised in Finnish universities even if it has been challenged by many reforms that emphasize organizational values and practices. Academics in high positions, such as professors and deans, exercise their powers in many ways, for example, when bolstering the work and careers of their "own staff". In such an environment, motivation and competence are highly valued, and networks and collegial relations hold great significance in the progression of academic work and careers. 


\section{Discussion and conclusions}

Global management trends have been influencing all public organizations, including universities. In addition to changes resulting from the transforming environment, the academic profession is undergoing several internal alterations. Considering that it has been confined to opaque and obscure career paths, which have had a negative impact on opportunities to proceed in academic careers, the academic profession is in great need of change. However, new practices, such as the implementation of one-size-fits-all structures, have caused much criticism among academics, as they can be considered good for some but bad for many.

In this study, the empirical data was collected from Finnish universities. However, both, our theoretical discussion and empirical data shows that the trends are similar in national and international levels. Based on interview data gathered from the top and middle managers of four Finnish universities, it seems that the academic profession in Finland has been changing in many different ways, but it has also maintained a degree of continuity (Evetts 2009). While change and continuity are not opposite by nature, several contradictions and tensions exist between them, as well as simultaneousness.

Regarding organizational professionalism, we found that management is increasingly emphasized in Finnish universities, as evidenced by the growing power of manager-academics. One clear evidence of growing emphasis of managers is the "management careers" that are available also to professional managers from the private sector, creating tension in academic environment when they lack understanding of the academic work. In addition, academic work is increasingly managed and monitored, which is reinforced by new career models that link promotion straight to performance. New career structures, recruitment processes, and other practices have become standardized, leading to the criticism that the diverse needs of academics are not acknowledged. However, top and middle managers also perceive that standardization has clarified academic career structures and salary development. This aspect was brought up also by Evetts (2018), as she stated that human resource management (HRM) procedures in organizations have improved diversity and equal opportunities for professionals, since they have replaced old practices based on social networking. However, she thinks that career inequalities continue to exist in many ways. It has to also be taken into consideration that the massification process has diversified the group of academic professionals that used to be a rather small, elite group of professors. The increasing amount of researchers has also lead to more competitive environment. The competition occurs in all levels in higher education, and its negative influences in the system in general have not been still completely acknowledged (Naidoo 2016).

Occupational professionalism (Evetts 2009) is also deeply rooted in the practices of Finnish universities. From the interviews, it is clear that the authority has remained also within the academic profession; for example, professors and deans have the power in recruitments and manage financial matters at the faculty level (however, some are holding also the management position). There is also a strong emphasis placed on competence and motivation in academic work and careers. However, some old practices that exist should be renewed, such as a traditional work culture that places women at a disadvantaged position in academia (e.g., Huopalainen and Satama 2018; Nokkala et al. forthcoming). In addition to these characteristics, academic work is often referred to as a "vocation", which emphasizes an inner calling to science and motivations other than monetary rewards. Considering the low salary and rather poor working conditions that junior-level academics must bear for many years before they can (perhaps) be promoted, this still holds true in many universities (e.g., Brechelmacher et al. 
2015; Siekkinen et al. 2016b; Aarnikoivu et al. 2019). This perspective represents the other example of poor working culture that should be renewed so that academic career would be a more attractive career choice.

In this article, our analytical framework was based on the duality between professional and organizational values. However, the idea of hybridism was also introduced, which "arises when professional and managerial principles come together" (Noordegraaf 2015, pp. 2-3; see also Brückmann \& Carvalho 2018 ). We emphasize that the transformation of the academic profession is a hybrid process that includes both organizational and professional values and practices. It is also evident that it would be an over simplification to categorize the change related to the organizational and continuity only to the professional. In higher learning and work of academic profession, organizational values and processes have always played an important role. University as an organization has always been an organizational frame for academics (Musselin 2013). On the other hand, also professional values and identities are changing and continuing not only because they reflect on organizational changes but also because of changing values and norms of academic work and science that are progressive by their nature. Change can be internal or/and external by its nature (Saarinen and Välimaa 2012). Thus, hybridization of academic work is caused by an interplay between changes and continuities in both spheres.

Changes in professional values and practices include the causalisation of professional work; internal requirements for equality, transparency and fairness, and requirements for efficiency, control, and increasing competition, which are caused by pressures coming from outside the profession. Continuities in professional values and practices include the significance of inner calling; motivation and competence; work culture; the disciplinary differences; the power and authority of professors; prestige; competition (which is also a traditional feature of academic work), and traditional academic identity and roles in teaching and research. Changes in

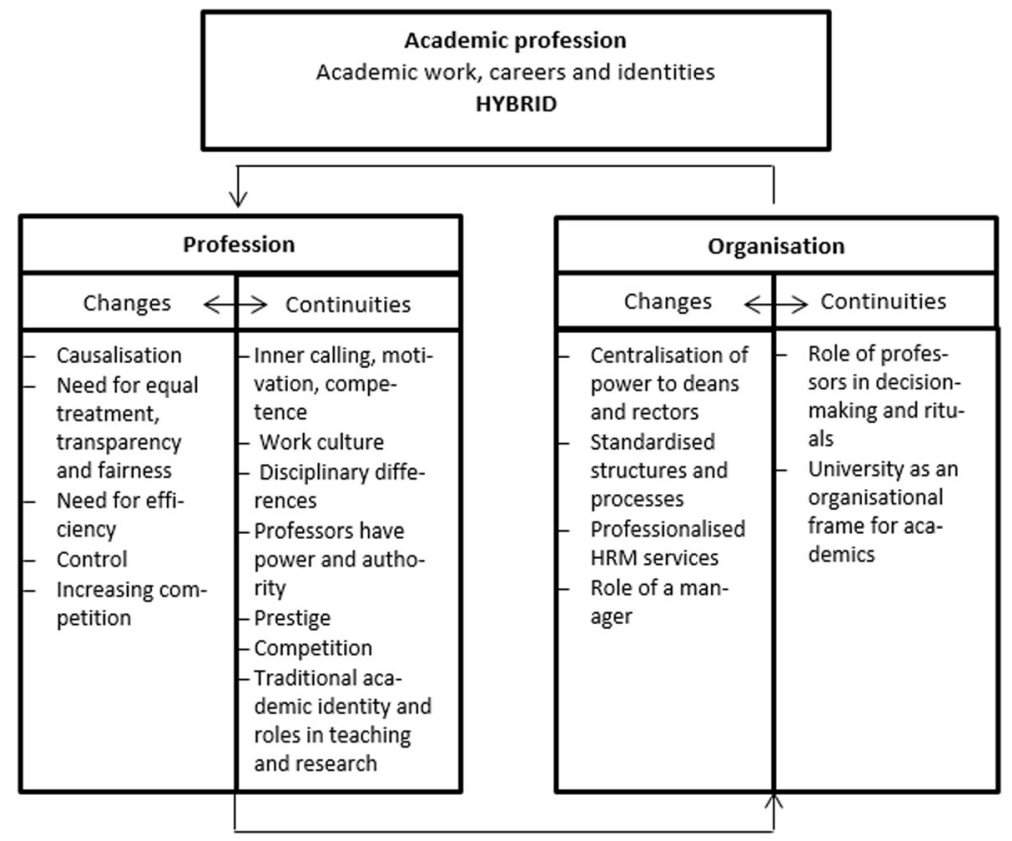

Fig. 1 Organizational and professional dimensions of the hybrid academic profession 
organizational values and practices include the centralization of power towards deans and rectors and the development of standardized structures and processes, professionalized HRM services and new roles (and careers) related to management, while its continuities include the power of professors and the university's role as an organizational frame for academics (Fig. 1).

In spite of their hybrid nature, tensions occur when academics are pursuing to integrate these both aspects in their work to be able to perform in a changing environment with varying expectations. To be able to achieve the competitive edge in a global competition, universities have to have both; good management and excellent scientific quality (see Tight 2014). When universities are becoming hybrids, meaning that they are operating in a different environments with diversified functions (Johanson and Vakkuri 2018), academic profession is reflecting this change (Musselin 2007), and become as hybrid as well by creating new, blurred roles and identities. To determine how these two logics could co-exist in universities, as well as how universities could provide more "meaningfully managed professional work" (Noordegraaf 2015), the preconditions and implications of hybrid academic professionalism and hybrid academic work should be studied more.

Funding Information Open access funding provided by University of Jyväskylä (JYU). This work was financially supported by the following projects: project POCI-01-0145-FEDER-029427- funded by FEDER, through COMPETE2020 - Programa Operacional Competitividade e Internacionalização (POCI), and by national funds (OE), through FCT/MCTES. And a project: HYPER - Performance Measurement for Hybrid Governance, 2017-2021, Academy of Finland (309134).

Open Access This article is distributed under the terms of the Creative Commons Attribution 4.0 International License (http://creativecommons.org/licenses/by/4.0/), which permits unrestricted use, distribution, and reproduction in any medium, provided you give appropriate credit to the original author(s) and the source, provide a link to the Creative Commons license, and indicate if changes were made.

\section{References}

Aarnikoivu, M., Nokkala, T., Siekkinen, T., Kuoppala, K., \& Pekkola, E. (2019). Working outside academia? Perceptions of early-career, fixed-term researchers of changing careers. European Journal of Higher Education. Online 11 January 2019. https://doi.org/10.1080/21568235.2018.1548941.

Ball, S. J. (1997). Policy sociology and critical social research: a personal review of recent education policy and policy research. British Educational Research Journal, 23(3), 257-274.

Becher, T. (1989). Academic tribes and territories. Intellectual enquiry and the cultures of disciplines. Milton Keynes: The Society for Research into Higher Education.

Bleiklie, I., Enders, J., Lepori, B., \& Musselin, C. (2011). New public management, network governance and the university as a changing professional organization. In T. Christensen \& P. Laegreid (Eds.), The Ashgate research companion to new public management (pp. 161-176). New York: Routledge.

Brechelmacher, A., Park, E., Ates, G., \& Campbell, D. F. J. (2015). The rocky road to tenure - career paths in academia. In T. Fumasoli, G. Goastellec, \& B. M. Kehm (Eds.), Academic Work and Careers in Europe: Trends, Challenges, Perspectives (pp. 13-40). Springer international publishing.

Brückmann, S., \& Carvalho, T. (2018). Understanding change in higher education: an archetypal approach. Higher Education, 1-19 Published online 10.2.2018.

Carvalho, T. (2014). Changing connections between professionalism and managerialism: a case study of nursing in Portugal. Journal of Professions and Organization, 2014, 1-15. https://doi.org/10.1093/jpo/jou004.

Carvalho, T. (2017). The study of the academic profession-contributions from and to the sociology of professions. In J. Huisman \& M. Tight (Eds.), Theory and method in higher education research (pp. 59-76). Emerald Publishing Limited.

Carvalho, T., \& Diogo, S. (2018). Exploring the relationship between institutional and professional autonomy: a comparative study between Portugal and Finland. Journal of Higher Education Policy and Management, 40(1), 18-33. 
Carvalho, T., \& Santiago, R. (2010). New public management and 'middle management': how do deans influence institutional policies? In L. V. Meek, L. Goedegebuure, R. Santiago, \& T. Carvalho (Eds.), The changing dynamics of higher education middle management (pp. 165-196). Springer.

Clark, B. (1983). The higher education system. Academic organisation in crossnational perspective. Berkeley: University of California Press.

Deem, R. (1998). 'New managerialism' and higher education: the management of performances and cultures in universities in the United Kingdom. International Studies in Sociology of Education, 8(1), 47-70. https://oi. org/10.1080/0962021980020014.

Deem, R. (2004). The knowledge worker, the manager-academic and the contemporary UK university: new and old forms of public management? Financial Accountability \& Management, 20(2), 107-128.

Deem, R., \& Brehony, K. J. (2005). Management as ideology: the case of 'new managerialism' in higher education. Oxford Review of Education, 31(2), 217-235.

European Science Foundation. (2009). Research careers in Europe. Landscape and horizons. Report. The ESF member organisation forum on research careers. http://archives.esf.org/fileadmin/Public documents/Publications/moforum research careers.pdf. Accessed 01.06.2018.

Evetts, J. (2009). New professionalism and new public management: changes, continuities and consequences. Comparative Sociology, 8(2009), 247-266.

Evetts, J. (2010). Reconnecting professional occupations with professional organisations: risks and opportunities. In L. Svensson \& J. Evetts (Eds.), Sociology of professions: Continental and Anglo-Saxon traditions. Gothenburg: Bokförlaget Daidalos.

Evetts, J. (2018). Professions in turbulent times. Changes, challenges and opportunities. Sociologia-Problemas e práticas, (88), 43-59. https://doi.org/10.7458/SPP20188814797.

Ferlie, E., Musselin, C., \& Andresani, G. (2008). The steering of higher education systems: a public management perspective. Higher Education, 56, 325-348. https://doi.org/10.1007/s10734-008-9125-5.

Giddens, A. (1991). Modernity and self-identity. Cambridge: Polity Press.

Goode, W. J. (1957). Community within a community: the professions. American Sociological Review, 22(2), $194-200$.

Hendrikx, W., \& van Gestel, N. (2017). The emergence of hybrid professional roles: GPs and secondary school teachers in a context of public sector reform. Public Management Review, 19(8), 1105-1123.

Henkel, M. (2005). Academic identity and autonomy in a changing policy environment. Higher Education, 49(1-2), 155-176.

Höhle, E. A., \& Teichler, U. (2013). The academic profession in the light of comparative surveys. In B. M. Kehm \& U. Teichler (Eds.), The academic profession in Europe: New tasks and new challenges (pp. 23-38). Springer.

Hsieh, H.F. \& Shannon, S.E. (2005) Three approaches to qualitative content analysis. Qualitative Health Research, 15(9), 1277-1288. DOI: https://doi.org/10.1177/1049732305276687

Huopalainen, A. S., \& Satama, S. T. (2018). Mothers and researchers in the making: negotiating 'new' motherhood within the 'new' academia. Human Relations, 72(1), 98-121. https://doi.org/10.1177 /0018726718764571.

Jackson, A. Y., \& Mazzei, L. A. (2013). Plugging one text into another: thinking with theory in qualitative research. Qualitative Inquiry, 19(4), 261-271.

Johanson, J.-E., \& Vakkuri, J. (2018). Governing hybrid organisations. Exploring diversity of institutional life. Routledge.

Kallio, K.-M., \& Kallio, T. (2014). Management-by-results and performance measurement in universities. Implications for work motivation. Studies in Higher Education, 39(4), 574-589.

Kallio, K.-M., Kallio, T. J., Tienari, J., \& Hyvönen, T. (2015). Ethos at stake: performance management and academic work in universities. Human Relations, 69(3), 685-709.

Kivistö, J., Pekkola, E., \& Siekkinen, T. (2017). Latest reforms of doctoral education in Finland in light of recent European developments. The European Journal of Higher Education. Special issue: Reform and Collaboration in EU-China Doctoral Education. https://doi.org/10.1080/21568235.2017.1290881.

Kivistö, J., Pekkola, E., \& Pausits, A. (2019). Academic careers and promotions in Finland and Austria: system an institutional perspectives. In M. Mahat \& J. Tatebe (Eds.), Achieving academic promotion (surviving and thriving in academia, volume) (pp. 105-125).

Klikauer, T. (2015). What is managerialism? Critical Sociology, 41(7-8), 1103-1119. https://doi.org/10.1177 $/ 0896920513501351$.

Kogan, M., \& Teichler, U. (2007). Key challenges to the academic profession and its interface with management: some introductory thoughts. Paris; Kassel: International Centre for Higher Education Research-Kassel.

Lepori, B. (2016). Universities as hybrids. Applications of institutional logics theory to higher education. In: Huosman, J., \& Tight, M. (eds.), (2016) Theory and Method in Higher Education. Vol 2. Emerald Books. 
Marginson, S. (2008). Academic creativity under new public management: foundations for an investigation. Educational Theory, 58(3), 269-287.

Martin-Sardesai, A., \& Guthrie, J. (2018). Human capital loss in academic performance measurement system. Journal of Intellectual Capital, 19(1), 53-70. https://doi.org/10.1108/JIC-06-2017-0085.

Mcgivern, G., Currie, G., Ferlie, E., Fitzgerald, L., \& Waring, J. (2015). Hybrid manager-professionals' identity work: the maintenance and hybridization of medical professionalism in managerial contexts. Public Administration, 93, 412-432.

MEC (2008). Neliportainen tutkijanura. Opetusministeriön työryhmämuistioita ja selvityksiä 2007:17. The FourStage Research Career Model. Finnish Ministry of Education and Culture.

MEC (2018). Funding formula for universities: https://minedu.fi/en/steering-financing-and-agreements.. Accessed 1.5.2018

Musselin, C. (2007). Transformation of academic work: facts and analysis. In M. Kogan \& U. Teichler (Eds.), Key challenges to the academic profession (pp. 175-190). Paris; Kassel: International Centre for Higher Education Research-Kassel.

Musselin, C. (2013). Redefinition of the relationships between the academics and their universities. Higher Education, 65, 25-37. https://doi.org/10.1007/s10734-012-9579-3.

Naidoo, R. (2016). The competition fetish in higher education: varieties, animators and consequences. British Journal of Sociology of Education, 37(1), 1-10. https://doi.org/10.1080/01425692.2015.1116209.

Nokkala, T., Bataille, P., Siekkinen, T. \& Goastellec, G. (forthcoming). Academic career, international mobility and the national gender regimes: comparison of Swiss and Finnish polities. In L. Weimer \& T. Nokkala (eds.), CHER 2017 conference book. Brinn.

Noordegraaf, M. (2015). Hybrid professionalism and beyond: (new) forms of public professionalism in changing organizational and societal contexts. Journal of Professions and Organization, 0, 1-20. https://doi. org/10.1093/jpo/jov002.

Pekkola, E. (2009). Akateeminen professio Suomessa - valtakeskittymä vai kolmen luokan työntekijöitä? Politiikka, 51:4, 268-290.

Pekkola, E. (2014). Korkeakoulujen professio Suomessa - kehityskulkuja, käsitteitä ja ajankuvia. Akateeminen väitöskirja. Tampereen yliopisto, johtamiskorkeakoulu. Tampere: Tampere University Press.

Pekkola, E., Siekkinen, T., Kivistö, J., \& Lyytinen, A. (2018). Management and academic profession: comparing the Finnish professors with and without management positions. Studies in Higher Education. https:/doi. org/10.1080/03075079.2017.1294578.

Perking, H. (1969). Key profession: history of the Association of University Teachers. London: Routledge \& Kegan Paul.press.

Pietilä, M. (2015). Tenure track career system as a strategic instrument for academic leaders. European Journal of Higher Education. https://doi.org/10.1080/21568235.2015.1046466.

Rasmussen, B. (2015). From collegial organisation to strategic management of resources: changes in recruitment in a Norwegian University. Sage OPEN, July-September, 1-11.

Saarinen, T., \& Välimaa, J. (2012). Change as an intellectual device and as an object of research. In B. Stensaker, J. Välimaa, \& C. S. Sarrico (Eds.), Managing reform in universities. Issues in higher education. London: Palgrave Macmillan.

Shah, M. (2013). Renewing strategic planning in universities at a time of uncertainty. Perspectives: Policy and Practice in Higher Education, 17(1), 24-29. https://doi.org/10.1080/13603108.2012.679753.

Shah, M., \& Sid Nair, C. (2014). Turning the ship around: rethinking strategy development and implementation in universities. Quality Assurance in Education, 22(2), 145-157. https://doi.org/10.1108/QAE-03-20120016.

Siekkinen, T., Pekkola, E., \& Kivistö, J. (2016a). Recruitments in Finnish universities: practicing strategic or pathetic HRM? Nordic Journal of Studies in Educational Policy, 2016(2), 32316. https://doi.org/10.3402 /nstep.v2.32316.

Siekkinen, T., Kuoppala, K., Pekkola, E., \& Välimaa, J. (2016b). Reciprocal commitment in academic careers? Finnish implications and international trends. European Journal of Higher Education. https://doi. org/10.1080/21568235.2016.1248990.

Siekkinen, T., Kivistö, J., Kuoppala, K., Pekkola, E. \& Nokkala, T. (2017). Nuorten tutkijoiden urilla eteneminen yliopistoissa - sattumaa vai suunnitelmallisuutta? [Young researchers proceeding in their careers - coincidence or a planning]. Tiedepolitiikka 4/2017.

Slaughter, S., \& Leslie, L. (1997). Academic capitalism. Politics, policies, and the entrepreneurial university. Baltimore: Johns Hopkins University Press.

Teichler, U. (2010). The diversifying academic profession. Continental and Anglo-Saxon traditions. Gothenburg: Bokförlaget Daidalos. 
Tight, M. (2014). Collegiality and managerialism: a false dichotomy? Evidence from the higher education literature. Tertiary Education and Management, 20(4), 294-306. https://doi.org/10.1080 $/ 13583883.2014 .956788$.

Välimaa, J. (1998). Culture and identity in higher education research. Higher Education, 36, 119-138 The Finnish Ministry of Education and Culture.

Välimaa, J. (2012). The corporatization of national universities in Finland. In B. Pusser, K. Kempner, S. Marginson, \& I. Odorika (Eds.), Universities and the public sphere. Knowledge creation and state building in the era of globalization (pp. 101-119). London: Routledge.

Välimaa, J., \& Weimer, L. (2014). The trends of internationalization in Finnish higher education. Zeitschrift für Pädagogik, 60(5), 696-709.

Välimaa, J., Aittola, H. \& Ursin, J. (2014). University mergers in Finland: mediating global competition. New directions for higher education. No. 168 (winter 2014). Wiley Periodicals, Inc. Published online. https://doi. org/10.1002/he.20112.

Välimaa, J., Stenvall, J., Siekkinen, T., Pekkola, E., Kivistö, J., Kuoppala, K., Aittola, H., \& Ursin, J. (2016). Neliportaisen tutkijanuramallin arviointihankkeen loppuraportti [The final report of the four- stage career model evaluation]. Opetus- ja kulttuuriministeriön julkaisuja, 2016, 15.

Vellamo, T., Siekkinen, T., Pekkola, E., \& Yuzhuo, C. (forthcoming). Technical identity in a merger process between a rock and a hard place. In L. Geshwind, A. Broström, \& K. Larsen (Eds.), Technical universities past, present and future. Springer Higher Education Dynamics series.

Vipunen. (2018). Education statistics Finland. https://vipunen.fi/en-gb/. Accessed 20.3.2019

Weber, M. (1978). Economy and society: an outline of interpretive sociology. Berkeley: University of California Press.

Whitchurch, C. (2008). Shifting identities and blurring boundaries: the emerge of third space professionals in UK higher education. Higher Education Quarterly, 62(4), 377-396. https://doi.org/10.1111/j.14682273.2008.00387.x.

Ylijoki, O.-H., \& Ursin, J. (2015). High-flyers and underdogs: the polarization of Finnish academic identities. In L. Evans \& J. Nixon (Eds.), Academic identities in higher education: the changing European landscape (pp. 187-202). London: Bloomsbury.

Publisher's note Springer Nature remains neutral with regard to jurisdictional claims in published maps and institutional affiliations. 